\title{
Urban courtyards: Ideologies of domesticity and the landscape of welfare in communist Bucharest
}

\author{
Iulia Stătică \\ The Bartlett School of Architecture, University College London, London, UK
}

\begin{abstract}
This article addresses the emergence of urban landscapes as a form of welfare tied to the provision of housing in pre-communist and communist Bucharest. Despite the importance of welfare landscapes in post-war capitalist Western Europe, this notion has been little addressed in relation to former communist countries in the Eastern Bloc. The case of Romania is exemplary in articulating how the phenomenon emerged within a planned economy where urban planning and housing provision were exclusively state-controlled. Welfare landscapes shifted during the communist regime, from their prior manifestation as a dense network of garden courtyards and public gardens to become a regulated system of parks with specific ideological purposes. This article proposes that state-planned welfare landscapes were paralleled by 'urban courtyards' that rescued the memory of the pre-communist garden city and informally established different extents of a 'good life' within standardised housing ensembles.
\end{abstract}

Keywords: urban courtyards, communism, domesticity, hospitality.

Contrary to the politics of welfare landscapes adopted in Western Europe - envisioned as extensions of post-war housing estates intended to contribute to inhabitants' well-being and community formation - in communism, welfare landscapes translated in the official discourse into mass programs intended to educate the people towards rational recreation. Seen as a resource of urban nature by the paternalist state, communist welfare landscapes were intended to contribute to the well-being and the healthy body of its productive citizens. The landscapes that materialized as a result of this state policy were characteristically of a large scale, constituting extensive parks serving several neighbourhoods. Despite the state's attempt to advance the well-being of the inhabitants through the promotion of the importance 
of green spaces and large-scale landscape projects, the small-scale green interventions within the housing estates - whereby greenery represents not only a rational source of energy and health, but also a space that is linked to a local community and to the domestic spaceremained, in the state discourse, an underdeveloped idea. This article proposes that within communism we may articulate a new typology of welfare landscape-in the form of urban courtyards. These were spaces delimited by domestic socialist blocks and constituted upon social structures and spatial practices rooted in the historical condition of the city. This article explores the phenomenon of the 'urban courtyard' as a critical element in the constitution of urban domesticities within the communist topography of Bucharest. It defines this infrastructural condition as a lacuna in the politics of welfare in the socialist state that manifested itself in the literal, spatial form of gaps between mass housing projects as unplanned landscapes of community. Through mechanisms of appropriation, these urban courtyards undermined the limits of the communalisation and socialisation that the state projected ideologically, contributing to the constitution of urban domesticity as a form of hospitality (Derrida, 2000).

The article's point of departure is the shift that occurred in Romania in the 1950s with the implementation of extensive reforms in urbanisation and industrialisation that radically changed the character and scale of the city, replacing individual houses with collective housing blocks related to spaces of production. New urban organisations - the cvartal and microrayon - reconfigured the city and imposed the Soviet structure of state-owned open green spaces shared by several residential buildings (Maxim, 2009). Embodying the complex relations of socialist mass modernity, the new urban elements attempted to combine the politically regulated experience of the urbanity they generated with an imposed rhythm of life. The large-scale zoning of the city — rigorously designed by the state - resulted, in spite of disciplinary planning agendas, in 'in-between' spaces. These were imagined functionally at best as, for example, parking spaces, but in practice they were dynamically appropriated through small-scale articulations. These newly emerged urban courtyards were able to form and accommodate communities, hide fragments of the old fabric, and serve as spaces for domestic and religious rituals, playgrounds, spaces of encounter, communal gardens, or spaces of subversion. The article asserts that the emergence of urban courtyards built on a 
genealogy of the garden courtyard was embedded within the urban structure of preCommunist Bucharest. Rescuing a historical urban practice, Communist urban courtyards facilitated successive transformations and appropriations of landscape infrastructures through everyday practices that superseded the particular ideological intentions built into their construction (Humphrey, 2005). It argues that urban courtyards became extensions of the domestic realm and anticipated a commons economy constituted around notions of care. Bringing into dialogue the notion of the commons (Federici, 2004) with that of hospitality (Derrida, 2000, 2001; Levinas, 1991) in order to investigate the manner in which the use of urban courtyards overcame increasingly controlling state policies, the article proposes that these courtyards became media through which a form of socialist governmentality ${ }^{1}$ based on the communalisation of landscape was constituted as a form of 'welfare'.

The article addresses 'the generative import' (Humphrey, 2005, p. 40) of the urban infrastructure and the way it interacted with people's imaginative everyday practices. Thus, the article turns away from a merely empirical analysis of these spaces, and employs literary texts as a critical source of sincere insight into people's intimate ways of appropriating space. This approach, which determines the employed methodology, builds on Caroline Humphrey's (2005) article 'Ideology and Infrastructure: Ideology and Soviet imagination' where she argues that the distance allowed by the literary text may be, in many instances, more valuable than the ethnographic research which can sometimes have its limitations such as lack of trust or inability to readily express thoughts in the interaction with the researcher (Humphrey, 2005, p.41). This article employs literary texts as a source of spatial ethnographies with the potential to give meaningful insights into the peculiar appropriation of the infrastructures designed with a specific political intention. Literature's encounter with the built environment is essential in order to show the refracted meanings that socialist state planning produced and the various ways in which the material and symbolic intersect within the everyday appropriation of the space.

\footnotetext{
${ }^{1}$ Governmentality, as envisioned by Foucault, refers to mechanisms of power that can employ 'a positive influence over life, that [endeavour] to administer, optimize, and multiply it, subjecting it to precise controls and comprehensive regulations' (Foucault, 1991, p. 137, cited in Agrawal, 2005, p. 217).
} 


\section{Genealogies of urban courtyards}

Public-gardens and courtyards played a fundamental role in the formation and development of Bucharest, in terms of both its territorial articulation and its socio-economic life (Tudora, 2010 , p. 76). We can talk about a topography of gardens that structured both domestic and social life. Georges Le Cler noted in 1866 that 'except for two or three streets where houses are joined, the rest of the dwellings are scattered, isolated, placed in the middle of a garden or courtyard' (Le Cler, 1886, cited in Tudora, 2010, p. 77). Later, in 1877, the French journalist Ulysse de Marsillac wrote that Bucharest had ' 658 streets, only 6 public squares and 60 public gardens' (de Marsillac, 1877, p. 32, cited in Toma, 2001, p. 24), apart from the individual garden courtyard that every house had. Public gardens were initially gardens owned by the nobility and opened to the public: 'common people would go with their families in the gardens that their owners open to the public and where wine and other drinks are served' (Recordon, 1821, cited in Toma, 2001, p. 26). Constituted as vast spaces of several hectares, public gardens belonged to a sacred topography (Toma, 2001, p. 28) insofar as their use was linked to the non-working days of religious celebration. ${ }^{2}$ The open, truly collective character of the public garden during religious celebrations was complemented by the image of communal tables of food that become a topos of Romanian imaginaries of Heaven (Toma, 2001, p. 30), transforming these gardens not only into a space for entertainment, but at the same time also into a space that structured the community's spiritual and symbolic life. On the other hand, garden courtyards were spaces around a household where domestic or semi-public activities would take place.

In Bucharest, the garden courtyard embodied an idea of nature that stood between production (vines, vegetables, fruit trees or beehives) and spontaneity, in opposition to the Enlightenment or Romantic English or French traditions, whereby gardens were a space where nature was controlled, and constantly repaired (Toma, 2001). Dedicated to interaction, entertainment and daily activities - and not to contemplation - courtyards were simultaneously kitchen, bathroom, bedroom, or workshop. Laundry, bathing and cooking would take place in these gardens, as well as socialisation and relaxation (Fig. 1 and 2), while farm animals,

\footnotetext{
2 In the Christian Orthodox tradition, important religious celebration days are free of work. "According to the estimate of Ulysse de Marsillac, there were about 52 religious "unworked" celebrations, as he specified, plus the Sundays, making a total of 104' (Toma, 2001, p. 29).
} 
specifically poultry, sheltered in chicken coops (Tudora, 2010, p. 83) would often

complement the vegetation and various activities. Garden-courtyards developed as an urban typology regulated by nature's rhythms, an extension of domestic space where, from spring to autumn, a motley growth of weeds, trees and flowers served as both utilitarian and aesthetic décor for semi-public activities. They were enclosed by low wooden or iron fences, with a wrought iron gate, allowing the private domain to be visible from the street. The courtyard unfolded around (or at least on three sides of) the house, which was oriented towards the street (Popescu, 2010, p. 151). Apart from their fictional and dreamlike dimensions, private gardens historically formed the core of Bucharest's neighbourhoods, domestic spaces being usually constructed around courtyards. These latter are often seen as symbolic landscapes encompassing imaginaries of an idealised city (Hirch, 1995; Hunt, 1992; Shur and Willerslev, 2013), as in the novels of Mircea Eliade (With the Gypsy Girls, The Forbidden Forest, In Dionysus Court etc.), where courtyards enveloped in green constitute thresholds to magic spaces. Eliade's novel With the Gypsy Girls (La țigănci) portrays the garden courtyard as a threshold between the real and the fantastic, the journey between which is guided by women.

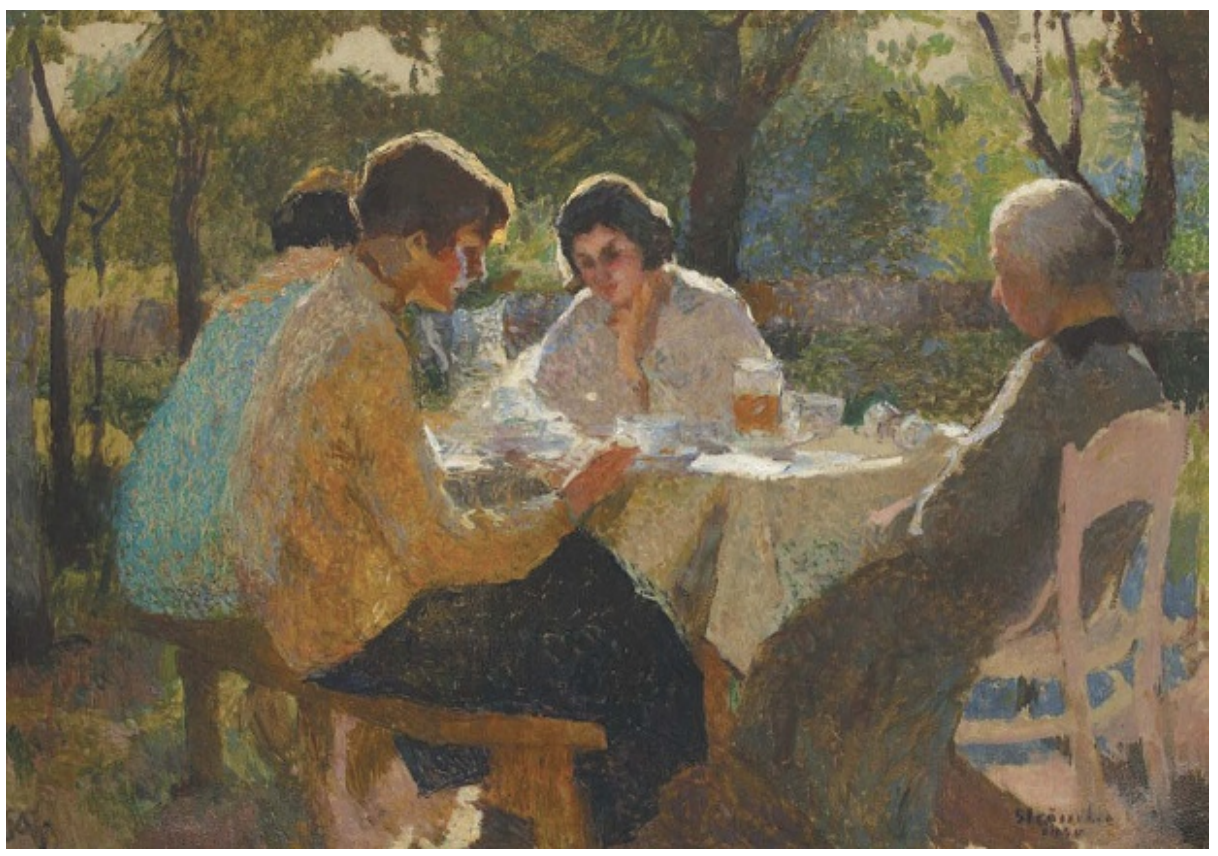

Figure 1. Ipolit Strâmbu³ (1871-1934) - In the Garden, 1930. Image in the public domain.

${ }^{3}$ See also Tudora (2010). 


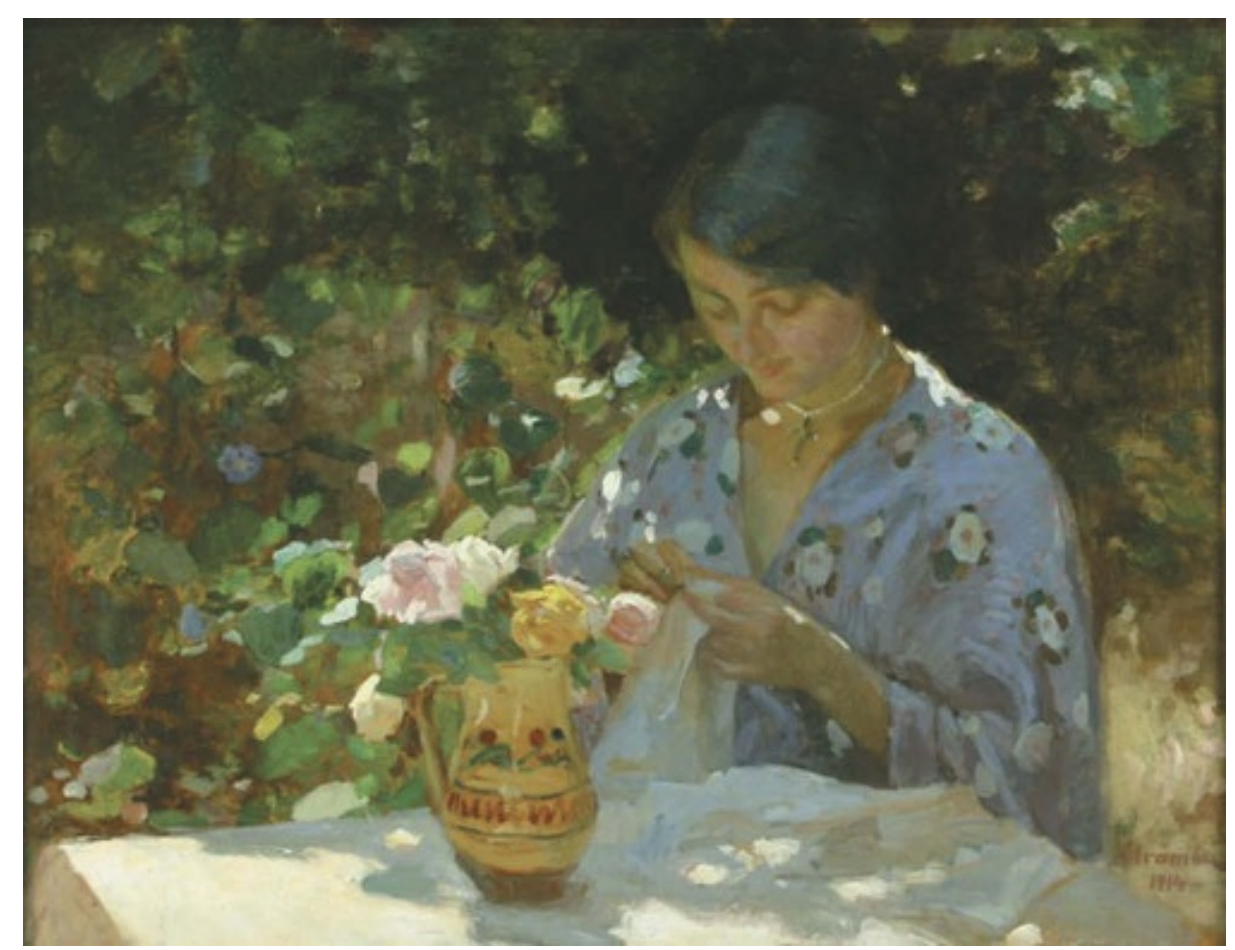

Figure 2. Ipolit Strâmbu - Women Embroidering in the Garden, 1914. Image in the public domain.

The main character, Mr Gavrilescu - a piano teacher - is hypnotically attracted by the unusual coolness and the odour of walnut leaves coming from the courtyard of a house belonging to gypsies, which he has passed for several years without noticing (Eliade, 2011). The garden - which from the outside looks beautiful and groomed, but is in fact full of random vegetation - is here a projection of the labyrinth, a space for initiation, and at the same time an image of Paradise.

Part of an urban landscape that developed within the framework of vernacular tradition, both the garden courtyard and the public garden contributed to the well-being of the residents. Developed either as an extension of the domestic space - the garden courtyard—or as a common territory for appropriation by the larger community - the public garden - they became vast welfare landscapes that structured pre-communist Bucharest as a form of 
interaction between private and public, concealing or enforcing boundaries in accordance with specific rhythms of nature and the community. ${ }^{4}$

\section{The Communist urban transformation and its ideology}

The transition to a socialist regime in 1947 radicalised the modernisation of the city through the implementation of principles of Soviet urbanism - with its focus on rationalisation and standardisation - based on an economy of production completely subordinated to the state. This process of industrialisation directed the growth of the urban population, through ruralto-urban migration, from 900,000 inhabitants in 1948 to 1,800,000 in 1977 (Mihăilescu, 2003, p. 165), determining an intense programme of housing construction. The 'housing laws' (Culiciu, 2016, p. 189) of 1952-1954 which regulated new housing and standardised the construction, layout and use of domestic units constituted the first step in the regulation of urban development intended to support the country's new productive character. Starting in the 1950s, architectural design became centralised in large institutes that were able to support the new technologies of construction and the development of type-projects (proiecte-tip) (Maxim, 2017, p. 54). The state was the only client, the State Committee for Architecture and Construction coordinated the design work at the national level, while the Institute of Design was in charge of all new projects within the city of Bucharest. Districts of housing blocks built in proximity to factories became the symbol of Communist modernisation and were used as a propaganda instrument.

In a first attempt to rescue patterns pertaining to the traditional dwelling structures that had been characteristic of Bucharest (Biciusca, 2006), between 1955 and 1957 architects employed new industrialised technologies of prefabrication to build a unique housing complex in Bucharest: Căţelu district (Fig. 3). The main architect of the complex, Tiberiu Niga, brought his interest in traditional Romanian architecture to the design of this project, which he was able to justify by associating vernacular forms with the politics of socialism

\footnotetext{
${ }^{4}$ Dolores Toma (2001) underlines the egalitarian character of these public gardens, comparing them to leisure or relaxation spaces in Paris. In the late eighteenth century one only needed a permit to use the public promenade Cours la Reine, whereas from 1830 onwards the emergence of public parks became an instrument of 'social control'. The function of new parks was to repress certain forms of popular entertainment and to impose specific formal, regulated social behaviours.
} 
expressed at that moment (Ioan, 2012, p. 224). The district comprised two- and three-storey housing blocks articulated around courtyards, constructed using Soviet imports of prefabricated concrete panels.

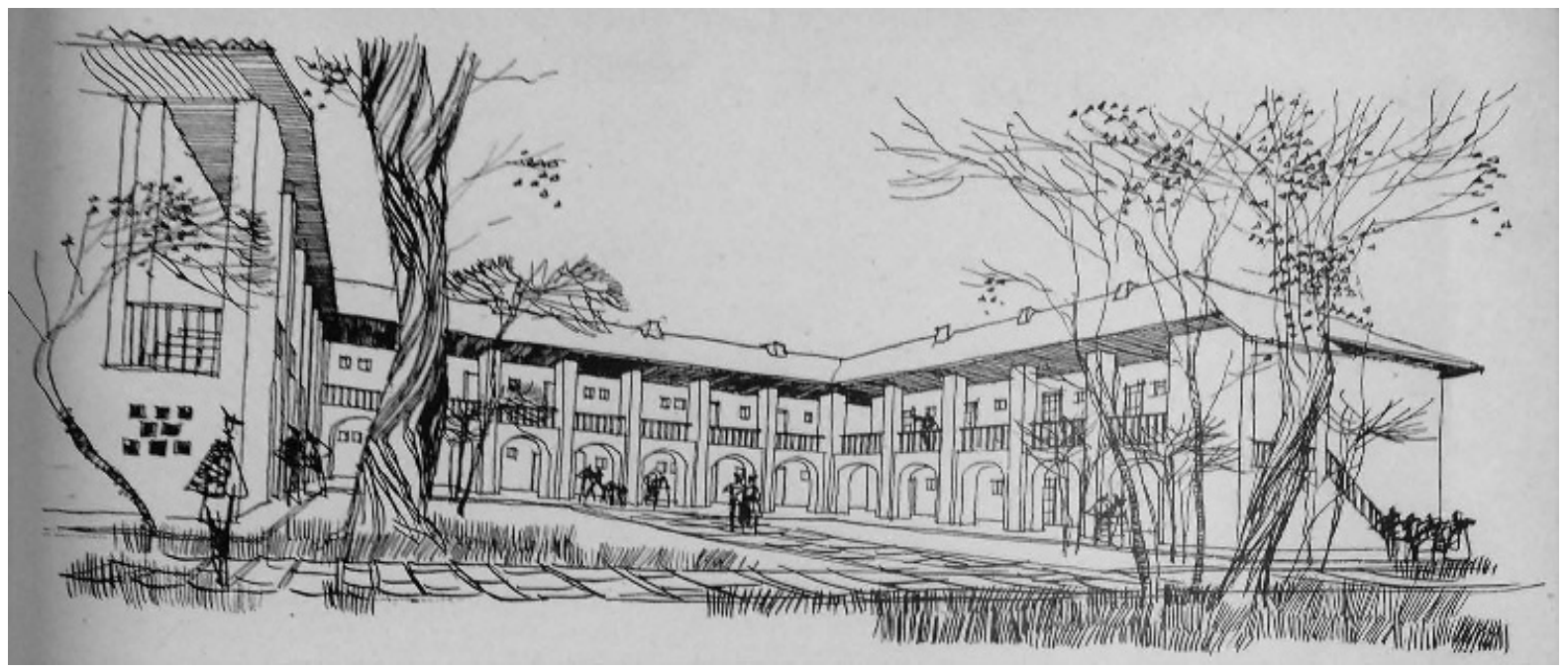

Figure 3. Căţelu District, Bucharest, Romania. Photograph published in Arhitectura RPR, no.2 (1957): 3. (C) Revista Arhitectura, Bucharest.

The housing block ensemble comprised more than 700 minimal apartments organised in 51 buildings (Niga, 1957, pp. 3-6). The modules consisted of one- or two-room apartments strung along the porches from one side of the building to the other (Biciusca, 2006, p. 17) that opened onto the courtyard. The porch, and by extension the courtyard, constituted the core of the community - a space for socialisation, which was appropriated as an extension of domestic space - and it was where most activities took place. Ensembles' courtyards started to be furnished with improvised seating and were usually covered with a grapevine pergola (Stătică, 2019a), an element recovered from the countryside, where it had not only served as productive planting but more importantly had also marked a space of encounter. These 'inbetween' spaces became filters between public and private, making the courtyard and the porch a succession of thresholds, with the space gradually losing its public character and gaining intimacy (Biciusca, 2006, p. 20). Căţelu district was a unique experiment whose principles were soon abandoned after its completion.

The challenge of mass housing demand brought about by the population increase found a solution in the standardisation and industrialisation of building materials and techniques. It materialized as a set of housing block typologies designed and produced to 
accommodate various family sizes, and repeated all over the city with minor modifications. The new urban transformation had to accommodate uprooted populations (Vişan, 2011, p. 55) who migrated from the countryside to work either in factories or on the building sites throughout the city. I interpret Derrida's notion of 'displaced persons' sharing different nostalgias (Derrida, 2000, p. 87) in relation to this context of internal migration in order to understand the nature of the phenomenon: the displacement and alienation of the population happened not only through the 'dis-location of the house' (Derrida, 2000, p. 91), but also through the imposition of a new paradigm for the construction of the house. The 'host' became the space itself, impregnated with a peculiar memory which, in spite of the politics of erasure, was already embedded as habitual and exploited architecture's ethics. This did not mean that ethics and politics became congruent, but they negotiated each other's position by pushing or restraining limits. The loss of the vernacular caused by socialist urban transformations 'brought about the uprooting of agrarian populations who then became as alienated from their traditional culture as they were from the objects of industrial production' (Frampton, 1998, p. 371). Mass housing replaced the individual houses (Maxim, 2009 , p. 8) while the small private gardens disappeared and were replaced by communal lawns and green spaces (Maxim, 2009, p. 13). These latter spaces that were neither private nor public emerged within the perimeter of an enclosure delimited by several housing units. In a first stage, the model of the cvartal was exported from the USSR at the end of World War II as a pattern to be applied by socialist countries in order to adhere to the newly emerged ideology. Groups of six to eight buildings - four- to five-storey height — situated around an orthogonal unbuilt space - the courtyard - formed the clusters that composed the cvartal. The transformation in scale was the radical factor that transformed the city, and the focus shifted from individual pursuits to state-designed neighbourhoods (Maxim, 2009, p. 8). The Romanian film Serenade for the 12th floor (Serenadă pentru etajul XII, 1976), directed by Carol Corfanta, portrays the passage from the traditional typology of the rural individual house with a garden to the standardised prefabricated apartment block (Stătică, 2019b). The scene showing the 'big day' when an entire community moves into a new housing district shows general images of the district: streets that are still unfinished, unplanted empty spaces between blocks, high-rise housing. The film — a comedy — was used as propaganda to 'educate' city dwellers and facilitate their 'voluntary' migration from individual houses to 
multistorey apartment buildings, emphasising the comfort and benefits of a rationalised lifestyle.

The planning model of large zoning instituted by the new ideology aimed to restructure the city according to four essential functions: production/industry, dwelling, planted spaces and services (Laurian, 1965). The new planning regime encouraged mass recreation through the building of large parks that also incorporated athletics facilities, in line with the state programme for the construction of healthy bodies to serve the state in both labour productivity and political activism. The official understanding of the welfare landscape shifted under the Communist regime, from a popular structure that negotiated between the private and the community to a state-controlled framework that incorporated numerous other facilities. Landscape and nature became infrastructures that articulated a form of mass welfare aiming to educate, improve and standardise behaviours and bodies. The belief that 'buildings and schedules would transform both flesh and consciousness' (Starks, 2008, p. 94) was at the core of the socialist policy, while the use of controlled leisure spaces was envisioned as countering the deleterious influences of street culture (Stark, 2008, p. 76) and informal gatherings. Nature was viewed as a resource (Koenker, 2008) within the rhetoric of health, and was placed at the heart of the socialist endeavour. As part of the housing zone, the microrayon constituted the main urban unit from 1958 onwards. This new urban form spatialised an ideal image of the socialist society (Maxim, 2017, p. 56), addressing the constitution of new subjectivities through the physical and social novelty that the state had designed: new urban forms, a new idea of domesticity (communal outdoor spaces, kitchens separate from living spaces, balconies etc.) (Maxim, 2017, p. 56) and new aesthetic forms - abstract and alienated from any traditional, familiar form. The shift proposed by this new urban paradigm entailed not only the formal transformation of domesticity but also the repression of the traditional understanding of the city. State-built multistorey prefabricated buildings with communal land that was shared by several buildings (Maxim, 2009, p. 9) replaced the traditional clusters of individual parcels containing family units (often accommodating multigenerational families). Envisioned as an urban unit that could function independently of the rest of the city, the microrayon embraced a variety of functions, such as kindergartens, schools, canteens, shopping centres, clinics/dispensaries, and large parks surrounded by streets of intense traffic (Laurian, 1965, p. 136). Within its 
boundaries the traffic was reduced as much as possible, and access was pedestrian (Laurian, 1965, p. 137). There were no aesthetic requirements for the new housing districts in Bucharest; they had only very functional aims: to respond as much as possible to the need for housing due to population growth and massive urban migration (Ionescu et al., 1969, p. 120). One of the most extensive housing projects built in Bucharest was Balta Alba district (Fig. 4). Situated in proximity to a major industrial area in the eastern part of Bucharest, it was composed of more than 36,000 apartments distributed across six neighbourhoods (cartiere), each of them formed by two to four microrayons (Ionescu et al., 1969, p. 120).

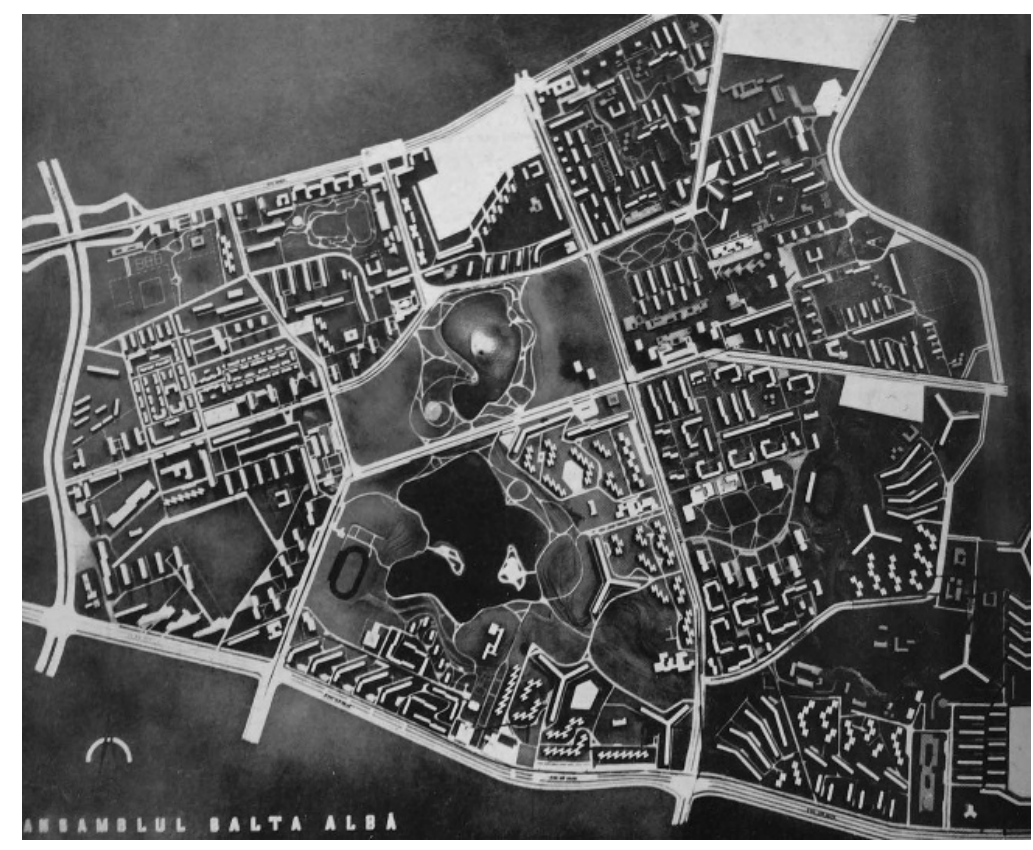

Figure 4. Balta Albă Housing District, Bucharest, Romania, 1966. Image published in Arhitectura, no. 4 (1966): 30. (C) Revista Arhitectura, Bucharest.

The microrayon accommodated — in standardised, industrially produced buildings — between 8,000 and 10,000 inhabitants (Ionescu et al., 1969, p. 120), with an 85-hectare park built in 1965-1970 - IOR Park ${ }^{5}$ - intended to serve as the population's leisure facility.

\footnotetext{
${ }^{5}$ The initialism IOR comes from the name of the Romanian Optical Enterprise, which was located in the neighbourhood.
} 


\section{Communist landscapes of 'ad hoc' welfare}

Typically, the backs of several housing blocks opened onto a vast space crossed by concrete alleyways and sometimes by planted earth (Fig.5). The courtyard defined this way, opened to the rest of the ensemble through a network of passageways that delimited the isolated housing blocks. The area of a courtyard varied although the relationship established between the ground and the surrounding housing blocks maintains almost always a sense of monumentality.

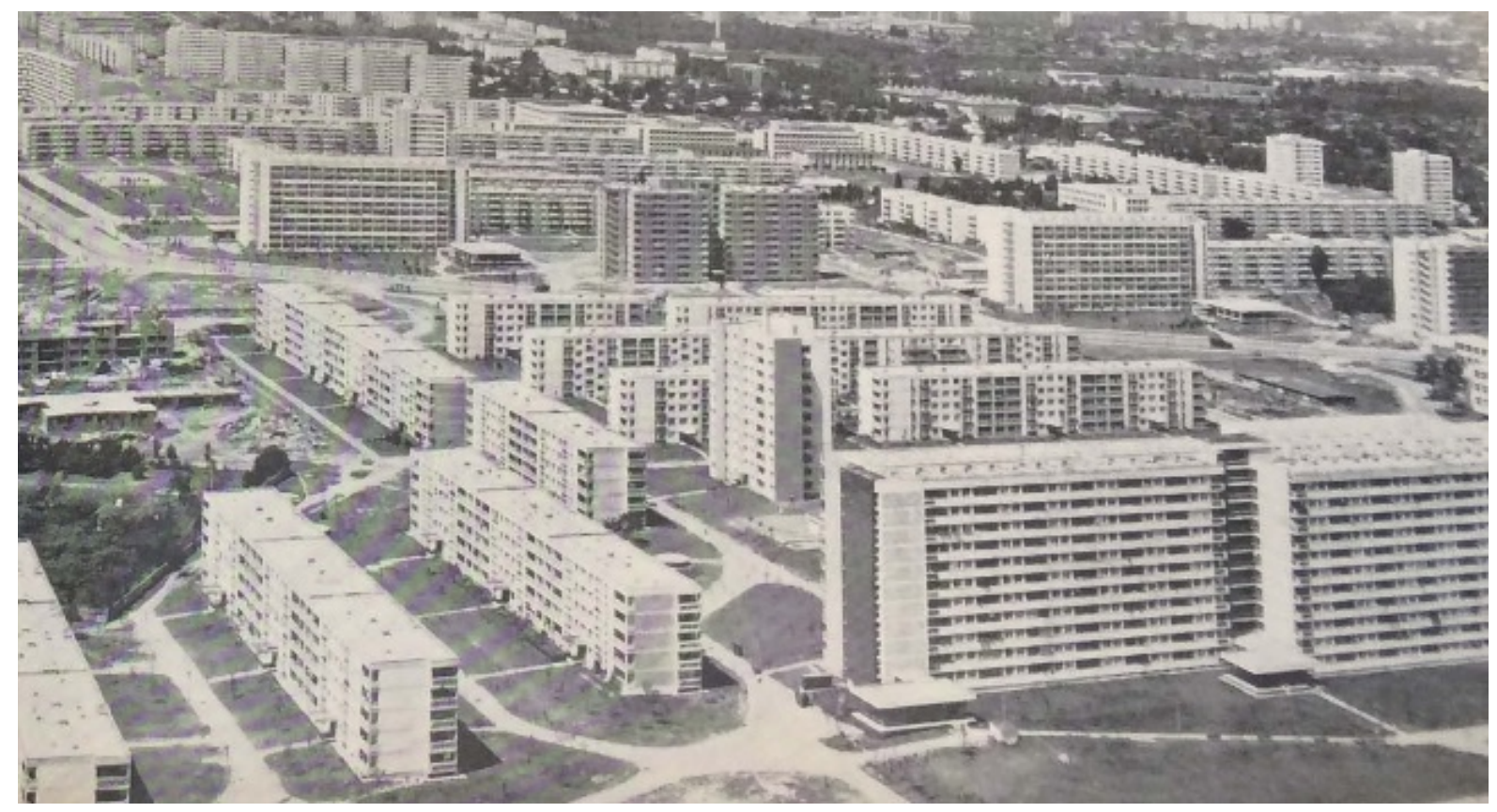

Figure 5. Balta Albă Housing District, Bucharest, Romania, 1967. Image published in Arhitectura, no. 4 (1967): 31. (C) Revista Arhitectura, Bucharest.

Through the temporary and improvised use of space, urban courtyards rescued the space between housing blocks as the centre of the domestic compound, playing both an aesthetic and a practical role. During Communism, the urban courtyard becomes an 'ad hoc' landscape of welfare constituted as an improvised extension of the domestic realm and a space for the articulation of a community - in opposition to the rigorously structured state-planned and controlled housing estates. The advent of 'ad hoc' welfare landscape builds on a genealogy of the garden that was at the core of pre-Communist Bucharest, and which developed in parallel to the standardised housing blocks and state-regulated leisure spaces. We may recognize three typologies of enclosures - constituted by five storeys housing buildings, by ten-twelve 
storeys, and by mixed ten-twelve and five storeys - while the ratio between the space of the garden and the footprint of the housing blocks seems to have rather minor variations whether we refer to the smaller courtyards (approx. 2000sqm) or to the larger ones (approx. 6000 sqm). ${ }^{6}$ Planting became a rationalised way to 'embellish' these wide, open spaces: regulated by straight lines, geometric forms that suggested the idea of human-made nature. The entrance to the housing space, through the back - usually discrete and not marked in any particular way - led to a narrow, dark hallway that contained all the doors of the apartments, with the staircase at the middle. Usually one housing block module comprised four apartments, compactly distributed around the staircase; not only was this a rational way to obtain uniformity in terms of the apartments' layout, but being able to see the entire hallway from the peephole of any apartment increased the sense of surveillance among the inhabitants. Each block had an administrator and a block committee to ensure that norms were followed. The same notion of surveillance extended to the courtyard, which was surrounded by the apartments' windows. Mara Wagner recounts in her novel Behind the block (In spatele blocului):

Through the kitchen window, cracked and supported with a jar of pickles [...] you could hear clearly the neighbours' voices from the courtyard of the block. When you cast your head out of the window, towards the narrow courtyard, surrounded by concrete walls, four storeys high, ${ }^{7}$ with windows beyond which other families lived, you learned how the neighbours lived. (Wagner, 2017, p. 7)

\footnotetext{
${ }^{6}$ Analysing plans of what I identify to fall into the category of communist urban courtyards in Bucharest the ratio between the area of the garden and the footprint of the housing district varied between $80 \%$ and $85 \%$. In Floreasca district the courtyard surrounded by five-storey housing blocks measured approx. 3000sqm while the footprint of housing units measured approx. 2500sqm. In Tineretului district the courtyard measured approx. 6000sqm, and the surrounding eleven-storey footprint of the housing units measured approx. 5000sqm. In Titan district the area of the courtyard was 2000 sqm, while the footprint of the mixed eleven and five-storey housing blocks was of approx. 1600 sqm.

7 In most of Europe, the first floor is considered to be the second level; therefore, a four-storey building is in fact a five-level building.

${ }^{8}$ All translations of passages of this novel from the original Romanian are mine.
} 
On the one side the constitution of these communist courtyards goes back to the traditional pre-communist gardens of Bucharest - they maintain the idea of extension of the home and of spaces for socialisation and community. On the other side, the above-mentioned idea of surveillance replaced the traditional use of these courtyards as spaces free of any political dimension. Caroline Humphrey's (2005) remark that even though socialist spaces allowed certain amounts of imagination, they had a limited spectrum whereby refracted practices were always within limits already embedded in infrastructure having their own socially regulated existence.

Mircea Cărtărescu's novel Blinding, originally published in 2007, is an evocation of the author's childhood and adolescence in a labyrinthine and phantasmagorical Bucharest under the Communist regime. The novel builds upon his family history and brings together, in a sort of magical realism, memories that are projected onto the concrete situation of housing as the spatial background for the enactment of life in Communist Bucharest. Detailed descriptions of apartment interiors, of the apartment block's communal corridors, of the staircase, streets or courtyards of the housing block, concretely situate the narrative. The courtyard emerging 'behind the blocks' develops into a theme that articulates passages between the city and the domestic realm; portrayed as a wondrous space, the courtyard accommodates multigenerational practices developed within the community, facilitating politicised actions meant to suppress old praxes, such as religion:

The churches from here, set on wheels, ${ }^{9}$ were transported like fantastic sacerdotal locomotives on the rails and led into obscure nooks, surrounded by blocks and left to degrade there, in courtyards full of rubbish bins, overflowing with sour vomit, that now leaned on some gentle painting of a saint's sandal, of the Virgin's hem. (Cărtărescu, 2007, p. 198) ${ }^{10}$

The image that Cărtărescu portrays is even more significant insofar as churches had a profound symbolic character for the constitution of Bucharest and historically they

\footnotetext{
9 Between 1977 and 1989, Bucharest lost 20 Orthodox churches (and several others were translocated) as well as six synagogues.

${ }^{10}$ All translations of passages of this novel from the original Romanian are mine.
} 
represented the centre of an urban district (mahala). In the new urban structure the factory replaced symbolically the church which represented only a marginal building, while the political practice restricted the religious rituals. Cărtărescu describes here an exceptional case $^{11}$ in which a system invented by Romanian engineer Eugeniu Iordăchescu saved some churches from demolition that involved literally moving the entire building from one place to another - usually behind the tall housing blocks, in the courtyards. The urban courtyard is portrayed as a fundamental space not only for accommodating common beliefs that historically structured the community, but also for one's imaginings of domesticity and its outdoors extension: 'Around nine in the morning, they were all gathered behind the block, at the furniture warehouse, and were comfortable lying on the floral sofas that had been taken out' (Cărtărescu, 2007, p. 253). Courtyards become in Mircea Cărtărescu’s narrative elaborate spaces in which specific rituals and leisure fuse in a space of the remembered or dreamed childhood that has a magical potential: 'He didn't even remember where those syllables came from, from some chicken feather probably, because people would cut the chickens' neck behind the block and they would then let them leap and writhe, headless, full of blood, until they froze on the ground' (Cărtărescu, 2007, p. 190).

The book offers a series of exemplary portraits in which imagination has worked with the concrete materiality of the courtyard and the socialities formed within it to produce 'an allegorical figure' (Humphrey, 2005, p. 51) that transcends the grey images of the Communist period with its shortages of food, heat or electricity and brings to light a landscape of welfare articulated within urban communities. It is probably only through literary text that we may articulate the properties that the space acquired in people's imagination, and that negotiated within that peculiar condition of shortage and political control possibilities for a good life:

In front of their window, which opened onto the block's courtyard, there was a garden of weed remnants among patches of land, where her mother would plant flowers in spring. [...] Some of them wanted to plant vegetables, others, including her mother, supported the idea of flowers. In the end there was no conclusion, so it remained a space where clothes could be hung out on the wire between the two thin birches, a space where children would play, a place where children played hide and seek in

\footnotetext{
${ }^{11}$ There were 11 cases in Bucharest where churches were moved away from planned housing sites.
} 
summer and built their fortress of snow in winter, or where sometimes in the evening teens gathered. At one time there appeared a wooden table and two benches built at some neighbours' initiative to play backgammon on Sunday mornings over a beer. (Wagner, 2017, p. 9)

Through all these descriptions - literary or ethnographic - the urban courtyard overcomes the abstraction of the unplanned space between blocks and becomes a vehicle for social cohesion and negotiation. Its constitution is not only social, and its spatiality it's very peculiar: a porous space, partially enclosed by the high housing blocks and in direct visual or physical connection with the home. As Humphrey (2005) remarks, in spite of the intentions invested in them, material objects always imply an unfinished abstraction, and can never be reduced to unidirectional forces (Harvey, 1997, p. 9). Similarly, the interaction between socialist government technologies and society manifested both through the imposition of a new set of controlled praxes and through the spatial and physical contexts themselves, in which the latter could be said to have allowed for 'human freedom and reflection' (Humphrey, 2005, p. 43). Recounted memories, whether actual or mediated through fiction, suggest that urban courtyards had meanings and effects that were compliant with the intentions embedded in their design but at the same time were refracted beyond the territory of the socialist political imagination, acquiring a 'prism-like quality' (Humphrey, 2005, p. 43).

\section{Urban courtyards: between hospitality and governmentality}

In the remaining space there were garages, vegetable and flower gardens, stretched wires for hanging clothes, they installed a carpet beater, a small table with three benches used by the retirees. We had a garden in the 1980s. After we built a garage, [...] we had to give up the space for a garden. In the garden we planted onion, garlic, tomatoes, carrots, parsley. [...] In the back there were plots with room for coops, everybody had chicken. [...] Our neighbours from the other stair [i.e. module of the block] had cherries, I would go to the harvesting since my mother would send me when she was making cherry pie. (Muzeul Țăranului Român, 2003, pp. 65-66) 
Numerous similar recounts of the dwellers of the housing districts articulate the space enclosed within the concrete walls in terms of a communalisation of land and landscape that, we might argue, establishes a peculiar connection with the notion of the commons (Fig. 6, 7).

These recounts evoke images of dynamic 'social cooperation' (Federici, 2011, p. 41) that were regulated through specific temporalities and activities. Situated halfway between the 'public' and the 'private', the notion of the commons suggests a wider idea of property that refers to social goods which-in spite of a regulatory framework imposed by the socialist state-a community collectively organises and controls (Federici, 2011, p. 41). The courtyard thus functions here in two ways: it memorialises and preserves a certain historical understanding of domesticity, and in this way it resists the uniformity which planning and standardised housing aim to effect. Domesticity is not only dependent on the private sphere; it extends into a public domain through an idea of community that gathers around an ad hoc topography of welfare. Urban courtyards become 'centers of sociality, knowledge production, cultural and intergenerational exchange' (Federici, 2012, p. 141, cited in Di Mauro, 2018, p. 4), challenging political intentions and constituting direct interventions in the production of urban space (Di Mauro, 2018, p. 4) and thus in the constitution of a landscape of welfare.

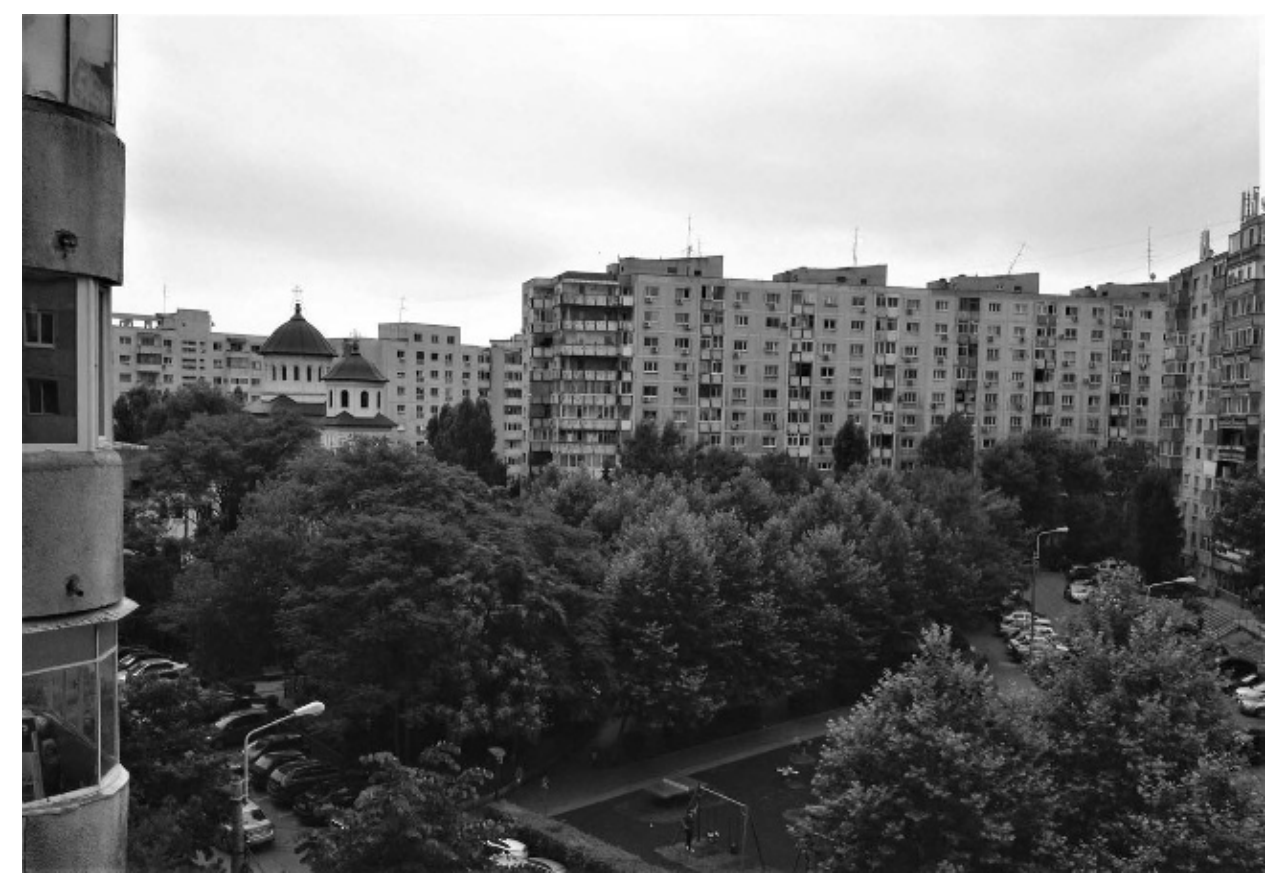

Figure 6. Urban courtyard in Tineretului housing district, Bucharest, Romania. Photo by the author, 2014 


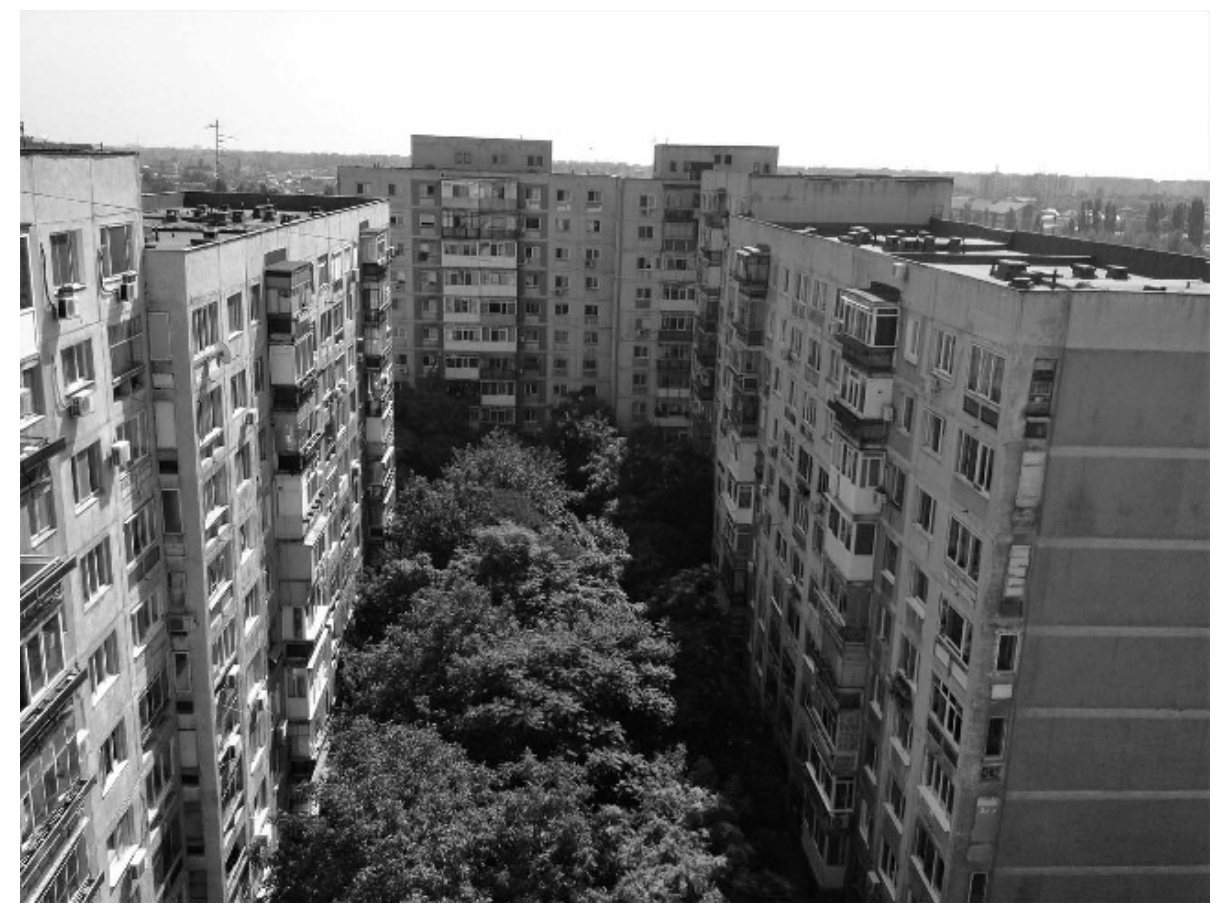

Figure 7. Urban courtyard in Militari housing district, Bucharest, Romania. Photo by the author, 2015.

They became a peculiar type of commons that involved expanding the realm of domesticity into the creation of living conditions beyond the prefabricated apartments through a collectivisation of care (Federici, 2012). I bring here this analogy between the communist urban courtyards and the commons insofar as the reinvention of the latter within a communist context becomes a peculiar space for the production of social processes. The possibility to even articulate such a space within this political context is extraordinary as its constitution transcends a merely resource-based definition; its most important aspect is the immaterial social dimension that this space makes possible (Hugill, 2015). If, from the point of view of the state, the factory was the main agent of socialisation, the courtyard becomes a noncommodified resource that needs continual contributions from active subjects, independent of any political intention (Petrescu, 2013, p. 262). As we have already seen, this 'semi-public' landscape enclosed by the housing blocks accommodated multiple practices, ranging from domestic work, childcare and play, elder care, farming and animal-rearing, storage for domestic goods, and religious practices. The foregrounding of care in the constitution of this topography — able to negotiate religious, symbolic or common everyday practices - generates an economy of reciprocity between the dwellers and the space that may be linked to structures of hospitality. Derrida (2001) suggests that hospitality is always about crossing 
thresholds whereby the host must be hospitable in order to preserve its identity, and 'the home must have some kind of opening in order to become home' (Rafn, 2013). Drawing on the French term hôte - meaning both 'guest' and 'host — both Levinas (1991) and Derrida (2001) articulate rich philosophies of hospitality that situate the dwelling, the home, as their main physical space of enquiry.

Hospitality is culture itself and not simply one ethic amongst others. In so far as it has to do with the ethos, that is, the residence, one's home, the familiar place of dwelling, inasmuch as it is a manner of being there, the manner in which we relate to ourselves and to others, to others as our own or as foreigners, ethics is hospitality; ethics is so thoroughly coextensive with the experience of hospitality. (Derrida, 2001, pp. 16-17)

In the case of the socialist urban courtyard, we may be able to address this double meaning of hôte in a peculiar way: the host would here be represented by the domestic infrastructure itself (i.e. urban courtyards), which both embodies the ideological intentions of the state and transcends them - as we have already seen, the host becomes the space accommodating the 'displaced population' - and is able to allow a certain space of freedom and negotiation. It may be related to what Derrida refers to as 'conditional' hospitality, which preserves or advances 'existing power hierarchies' (Hamington, 2010, p. 23). On the other hand, the residents are the guests, since their transition to the new domestic spaces occurs as an alienating process that is related to a radical transformation of the domestic realm and the urban landscape more generally. This interaction between infrastructure as host and residents as guests is further mediated by structures of care that the constitution of a community generates. Analysing Soviet hostels and courtyards, anthropologist Caroline Humphrey (2005, p. 55) observes that 'the built construction seems capable [...] of acting as if like a prism: gathering meanings and scattering them again, yet not randomly. As a prism has a given number of faces, the light it scatters has direction.' In a similar sense, Communist Bucharest's urban courtyard - that is the infrastructure - constitutes a medium or form of mediation that attempts to shape and regulate behaviours, but at the same time, it fosters a predisposition for openness and hospitality towards its dwellers that, in this encounter, are granted access to a variety of 'refracted practices'. Architecture and landscape's ability to 
orient subjective and intersubjective experiences and give space to hospitality is embedded in the urban tradition of the place and founded on a genealogy of urban courtyards that structured the entire life of the city in the pre-Communist period. The courtyard, which does not belong to anybody, becomes the space where hospitality is unfolded. The courtyard as a domain of hospitality becomes 'a structure that regulates relations between inside and outside, and, in that sense, between private and public' (Still, 2013, p. 11); it facilitates the transgression of increasingly controlling state policies, and becomes a tool for a sort of socialist governmentality. Under socialism, 'the welfare of the population, the improvement of its condition, the increase of wealth' become not the object of government (Foucault 1991, p. 100, cited in Agrawal, 2005, p. 219) but a set of social and domestic practices that, through modes of appropriation of space, subvert state politics to a certain extent, giving life to an economy of welfare that is fundamental to the functioning of the domestic space.

\section{Conclusion}

In spite of ideological programmes that impose certain patterns of life, space cannot be the unique result of technocratic construction, and its limits, although acknowledged, are always challenged by daily use. Literature gave us the some insight into the dynamics of these relations; its presence is not a mere metaphor for redrawing the imaginaries of the communist epoch, but becomes a source for spatial ethnographies showing that in spite of the politics of control employed by the repressive state politics, those ideologies could not 'shut down imagination' (Humphrey, 2005, p. 55). Literature helps us understand how communist architecture and urban planning negotiated levels of compliance and subversion, and conversely, how everyday practices interacted with the new structure of the city. Urban courtyards became a space of passage — between the private and the public, the domestic and the political - that opened up spaces for negotiation between the state's regulatory mechanisms and residents' everyday lives. The urban courtyard thus manifested a unique continuity with traditions of hospitality that were embedded in the historical structure of the city of Bucharest: it constituted a structure of generosity and an anticipation of a commons, based on the communalisation of landscape as a form of 'welfare'. 


\section{References}

Agrawal, A. (2005). Environmentality: Technologies of government and the making of subjects. Durham and London: Duke University Press.

Biciuşcă, F. (2006). Experimentul Căţelu. Bucharest: Paideia.

Cărtărescu, M. (2007). Orbitor: Aripa stângă. Bucharest: Humanitas.

Culiciu, C. (2016). Legislația locativă a româniei de la reconstrucție la demolări. Buletinul Cercurilor Ştiinţifice Studenţeşti, 22, 187-203.

de Marsillac, U. (1877). Guide du voyageur à Bucharest. Bucharest: Imprimerie del la Cour. Derrida. J. (2000). Of Hospitality. Stanford, CA: Stanford University Press.

Derrida, J. (2001). On Cosmopolitanism and Forgiveness. New York: Routledge.

Di Mauro, S. E. (2018) Urban community gardens, commons, and social reproduction: revisiting Silvia Federici's Revolution at point zero. Gender, Place and Culture. published online : 15 Mar 2018.

Eliade, M. La țigănci. Pe strada Mântuleasa. In curte la Dionis, Editura Art, București, 2011

Federici, S. (2004). Caliban and the witch. Brooklyn, NY: Automedia.

Federici, S. (2011). Women, land struggles, and the reconstruction of the commons. Journal of Labor and Society, 14(1), 41-56.

Federici, S. (2012). Revolution at point zero: Housework, reproduction, and feminist struggle. Oakland, CA: PM Press.

Frampton, K. (1998). The status of man and the status of his objects: A reading of The human condition. In M. Hays (Ed.), Architecture theory since 1968 (pp. 362-377). Cambridge, MA: MIT Press.

Foucault, M. (1991). Politics and the study of discourse and Governmentality, in The Foucault effect: Studies in governmentality, ed. G. Burchell, C. Gordon, and P. Miller. Chicago: University of Chicago Press. 53-72 and 87-104.

Hamington, M. (2010). Toward a theory of feminist hospitality. Feminist Formations, 22(1), $21-38$.

Harvey, P. (1997). Technology as skilled practice: Approaches from anthropology, history and psychology. Social Analysis, 41(1), 3-14. 
Hirsch, E. (1995). Introduction - Landscape: Between Place and Space. In The Anthropology of Landscape: Perspectives on Place and Space, (eds.) E. Hirsch and M. O’Hanlon, 1-30. Oxford: Clarendon Press.

Hugill, A. (2015). Feminism and the commons. Guts, 5: Food/Land.

Humphrey, C. (2005). Ideology in infrastructure: Architecture and Soviet imagination. Journal of the Royal Anthropological Institute, 11(1), 39-58.

Hunt, John D. 1992. Gardens and the Picturesques: Studies in the History of Landscape Architecture. Cambridge: The MIT Press.

Koenker, D.P. (2008). The Right to Rest: Postwar Vacations in the Soviet Union. Seattle: The National Council for Eurasian and East European Research.

Ioan, A. (2012). Arhitectura (supra)realismului socialist. Bucharest: Paideia.

Ionescu, G., Derer, P., and Theodorescu, D. (1969). Arhitectura în România: Perioada anilor 1944-1969. Bucharest: Editura Academiei Republicii Socialiste România.

Laurian, R. (1965). Urbanismul. Bucharest: Technical Publishing House.

Le Cler, G. (1866). La Moldo-Valachie, ce qu'elle a été, ce qu'elle pourrait être. Paris: Librairie Éditeur F. Dentu.

Levinas, E. (1991). Totalité et infini: Essai sur l'extériorité. La Haye: Martinus Nijhoff. Maxim, J. (2009). Mass housing and collective experience: On the notion of microraion in Romania in the 1950s and 1960s. Journal of Architecture, 14(1), 7-26.

Maxim. J. (2017). Building the collective: Theories of the archaic in socialist modernism, Romania circa 1958. Rethinking Marxism, 29(1), 42-64.

Mihăilescu, V. M. (2003). Evolutia geografică a unui oraş: Bucureşti. Bucharest: Paideia. Muzeul Ţăranului Român (2003). Anii 80 şi bucureştenii. Bucharest: Paideia.

Niga, T. (1957). Un cartier de locuinţe minimale în Bucureşti: Loturile 3 şi 4 Şoseaua Mihai Bravu. Arhitectura RPR, 2, 3-11.

Petrescu, D. (2013). Gardeners of commons, for the most part, women. In P. Rawes (Ed.), Architectural ecologies: Architecture, nature and subjectivity (pp. 261-274). London: Routledge.

Popescu, I. (2010). Un cartier bucureştean, din perspectiva home ethnology. In A. M. Zahariade and A. Oroveanu (Eds), ACUM dosare bucureştene: Spaţiul public şi 
reinserţia socială a proiectului artistic şi arhitectural (pp. 146-153). Bucharest:

Editura Universitară 'Ion Mincu'.

Rafn, S. (2013). Jacques Derrida: Of Hospitality. visAvis: Voices on Asylum and Migration.

February 2013. Retrieved from http://www.visavis.dk/2013/02/jacques-derrida-ofhospitality/

Recordon, F. (1821). Lettres sur la Valachie. Paris: Lecointe et Durey.

Suhr, C. and Willerslev R., Eds. (2013). Transcultural Montage, New York, Oxford: Berghahn.

Starks, T. (2008). The body Soviet: Propaganda, hygiene, and the revolutionary state. Madison: University of Wisconsin Press.

Stătică, I. (2019a) 'Overlapping Nostalgias: Negotiating Space and Labor in the (Post)Communist City of Bucharest', Space and Culture, first published online 2019.

Stătică, I. (2019b) 'Socialist Domestic Infrastructures and the Politics of the Body: Bucharest and Havana', In A. Skrodzka, X. Lu, and K. Marciniak (Eds) The Oxford Handbook of Communist Visual Cultures, Online publication October 2019.

Still, J. (2013). Derrida and hospitality: Theory and practice. Edinburgh: Edinburgh University Press.

Toma, D. (2001). Despre grădini şi modurile lor de folosire. Iaşi: Polirom.

Tudora, I. (2010). Rolul grădinilor şi prezenţa lor în peisajul bucureştean. In A. M. Zahariade and A. Oroveanu (Eds), ACUM dosare bucureştene: Spaţiul public şi reinserţia socială a proiectului artistic şi arhitectural (pp. 74-99). Bucharest: Editura Universitară 'Ion Mincu'.

Vişan, L. (2011). Partially color: Rethinking exterior and interior spaces in Communist Romania. Anthropology of East Europe Review, 29(2), 51-66.

Wagner, M. (2017). In spatele blocului. Bucharest: Nemira. 